Saint Louis University School of Law

Scholarship Commons

All Faculty Scholarship

1990

\title{
The Fear of Liability and the Use of Restraints in Nursing Homes
}

Sandra H. Johnson

Saint Louis University School of Law

Follow this and additional works at: https://scholarship.law.slu.edu/faculty

Part of the Health Law and Policy Commons

\section{Recommended Citation}

Johnson, Sandra H., The Fear of Liability and the Use of Restraints in Nursing Homes (1990). Responsible Caring: Ethics Resources for Nursing Homes, Hastings Center, 1991.

This Article is brought to you for free and open access by Scholarship Commons. It has been accepted for inclusion in All Faculty Scholarship by an authorized administrator of Scholarship Commons. For more information, please contact erika.cohn@slu.edu, ingah.daviscrawford@slu.edu. 


\title{
The Fear of Liability and the Use of Restraints in Nursing Homes
}

\author{
Sandra H. Johnson
}

The routine use of chemical and physical restraints in nursing homes is bad care. 1 Medical and nursing literature on the care of nursing home patients consistently criticizes the use of restraints when that use is unrelated to diagnosis and treatment considerations. ${ }^{2}$ Federal and state laws have included restrictions on the use of restraints for some time. ${ }^{3}$ The criticisms of inappropriate and indiscriminate use of chemical and physical restraints are not new. What, then, supports their continued misuse ${ }^{4}$ despite the ordinarily powerful combination of professional and governmental approbation?

\section{The Problem with Restraints}

The use of restraints responds to generally quite acceptable and desirable patient-oriented goals. Restraints are used in an attempt to protect the patient with physical or mental disabilities from avoidable injury caused by falling or wandering away from the facility. In the social context of nursing homes, restraints are also used to protect residents from injury by threatening, violent patients. ${ }^{5}$ When the rationale is measured against the known effects of restraints, however, the self-evident nature of the justification begins to break down.

Research has yet to provide an empirical basis to support the customary uses of restraints. ${ }^{6}$ The risks of using restraints on elderly patients are serious and substantial. These risks include strangulation, ${ }^{7}$ medical ailments caused by immobility ${ }^{8}$ and increased agitation. ${ }^{9}$ In addition, restraints can lead to misdiagnoses due to masking of symptoms or assumptions that restraints are causing symptomatic behaviors. ${ }^{10}$ Men and women who have been restrained provide poignant testimony of the human costs of restraint: "I felt like a dog and cried all night. It hurt me to have to be tied up. I felt like I was nobody, that I was dirt." 11

As with any clinical decision, less harmful but equally effective options should be chosen whenever possible. There are effective alternatives to restraints, including door alarms, staffing changes, and environmental alterations that lessen the risks of falls and unsupervised travel. ${ }^{12}$ Reimbursement levels ${ }^{13}$ and regulatory policies ${ }^{14}$ influence the use of these aiternatives, although it would be incorrect to assume that they are necessarily more costly than restraints. 15

Perhaps the most subtle and pervasive force supporting the excessive use of restraints on nursing home residents is the expectation that nursing home care should at least be custodial. Nursing homes are the "keepers" and "guardians" of their elderly residents. They "protect," "confine," and "shelter" a most vulnerable group. No one would argue that safety and protection are not desirable in a nursing home. When methods used to keep residents safe from injury substantially interfere with other important goals, however, both the methods and the relative value of the goals need to be examined.

The goals of functional rehabilitation and maintenance are diminished in the face of a "therapeutic nihilism" that accepts the view that decline is inevitable. ${ }^{16}$ This view transforms the minimum expectation of custodial care to the primary goal. Risks assumed by others for the purpose of personal achievement or self realization easily become unacceptable if there is a less visible or less dramatic payoff. In contrast, the expectations of nursing home residents balance a desire for safety and a desire for function. In a survey of 455 residents in 107 nursing homes, the residents identified a safe and secure environment as a high priority; but they also ranked high on their list "as much independence as possible, with 
the opportunity to help themselves whenever possible, whatever the level of their ability." 17

The problem with restraints is that they are not "all bad." They truly present a dilemma that involves what one scholar has termed, "primal philosophical and experiential tensions: between freedom and best interest, self-determination and dependence on others, individual choice and the pressures of collective care." 18 But even those who understand the balance that needs to be struck and who are willing to invest more fully in protecting the functional capacity and autonomy of nursing home residents complain that the risk of legal liability forces them to restrain their patients.

A nursing home administrator attributed his facility's use of restraints to his perception that attorneys and families are "wanting and willing to sue if a home doesn't use protective devices to protect the resident." His facility, which opened as a "restraint-free" institution 12 years ago, now restrains $20-30$ percent of its residents "under pressure from insurance carriers, doctors and families." 19

A board-certified internist in his second year of a geriatrics fellowship wrote the New England Journal of Medicine about his concern over the use of restraints in nursing homes:

My malpractice insurance carrier periodically sends out a newsietter apprising its subscribers of potential risks for litigation. Recently, it warned that patients' falls and resultant injuries, especially hip fracture in the elderly, commonly lead to malpractice claims. ... The newsletter admonished physicians to be "careful in writing such orders" [for restraints and ambulation] and to make them "complete and specific," which I interpreted as urging their use whenever a chance of falling exists. ... Furthermore, in my own experience on acute care wards and in nursing homes, I have found that it is difficult to persuade the staff to unbind patients once they have shown any sign of frailty, because of the fear of liability. ${ }^{20}$

There is no doubt that the legal system plays a role in risk aversion and the use of restraints in nursing homes. The two major sources of legal incentives and disincentives for administrative and clinical decisions in nursing homes are negligence/malpractice litigation and public regulation. Although each has an impact on the use of restraints, this article focuses on civil liability; the discussion of regulation of the use of restraints is limited to its relevance to private litigation.

\section{Negligence/Malpractice Litigation on Restraints}

Injuries suffered in falls and while wandering are dramatic and acute events. They attract attention. Injuries to frail individuals can be much more severe than those suffered by younger people, leading to death in some cases. 21 In contrast, the slow deterioration of a person caused or exacerbated by inappropriate restraints or medication simply may meet expectations as an unavidable consequence of age and institutionalization. 22

Family members may expect that restraints should be used and that their absence reflects bad care. At the same time, family members are the most likely plaintiffs in litigation against nursing homes.

Perceptions of liability risks can be inflated, of course, and do not always withstand examination. To the extent that perceptions influence behavior, they are well worth measuring against the facts.

Litigation over injuries to nursing home residents is not common. Older people do not file negligence suits at nearly the rate of younger people. Empirical research on the rate of malpractice filings discovered that "the probability of an elderly person's filing a claim, given a potentially actionable injury, is roughly one-fourth that of persons under 65."23 There are many reasons for the low incidence of lawsuits. Recoverable damages tend to be low; causation is difficult to prove; and the resident often does not offer credible testimony. ${ }^{24}$

A database of cases filed in 52 cities, including some of the largest in the country, lists 247 cases filed against nursing homes over a period of four years. ${ }^{25}$ The database lists over 2000 cases filed against hospitals during the same period of time. The incidents described in the claims filed against nursing homes included bedsores, misdiagnosis, and medical treatment errors, as well as injuries due to falls and wandering. The database on claims filed provides only a very brief description of the claim, usually only a line or two; but a rough categorization of events underlying claims can be accomplished with the information provided.

Of the 247 cases filed on behalf of nursing home residents, four involved wandering and 60 involved residents who had been injured in falls. Of those, 20 specify no more than that the resident was injured in a fall; nine indicate a fall from a wheelchair; seven, falls in the bathroom; and three, falls from a window or balcony. The largest number of falls involved residents falling from beds, accounting for 21 clains. Among those claims indicating the alleged negligent acts of the facility, 16 claimed failure to supervise and eight claimed failure to restrain, including three claim- 
ing failure to use bedrails. There were also two claims for patients injured while restrained and two claiming negligent administration of sedatives and tranquilizers. The number of claims based on injuries in falls is challenged only by those claiming medical error/misdiagnosis (52) and bedsores (32).

Reported cases involving restraints are quite few in number. There are several reported cases in which the facility was held not liable for injuries suffered due to wandering or to falls. Some cases in fact indicate judicial support for the decisions not to use restraints.

The appellate court affirmed a jury verdict in favor of the provider in Nichols $\nu$. Green Acres Rest Home, Inc., 26 in which a resident left the facility and died, possibly by drowning in a puddle near a river on the facility's property. The deceased resident's physician testified that he had "absolutely no reason" to advise the nursing home to limit the resident's activities or to prevent him from strolling around the premises. The appellate court described the resident as a person who was still in reasonably good health and who enjoyed walking around the grounds even though he used a cane. The court was impressed with the fact that the facility exceeded the licensure standards for staffing and noted that it was "giving more than was required." Of course, the more typical cases generally involve residents who are mentally or physically disabled.

In Kildron v. Shady Oaks Nursing Home, ${ }^{27}$ for example, the appellate court affirmed the trial court's judgment that the nursing home provided reasonable care for an Alzheimer's patient who fell while unattended. The patient in this case became agitated and aggressive if restrained, so the facility let him wander and assigned an attendant to follow him if he went outside during the day. During the evening when the residents were settling down, a nurse's aide had responsibility for 12 to 16 residents. It was at this time that the resident fell in his room. The court found that the facility had no reason to believe that the resident was at a high risk of falling and that even if an attendant had been there, she would have been unable to prevent the fall.

The plaintiff in Brown v. University Nursing Home, Inc., ${ }^{28}$ claimed damages for injuries suffered in a fall when the resident attempted to walk unattended. The resident's physician had encouraged the facility staff to keep the patient ambulatory, and the facility had restrained the patient infrequently and then only with a restraining tray chair. The jury entered judgment in favor of the facility, and the appellate court upheld that judgment, 29 stating that "the fall of an elderly person does not necessarily result alone from the negligence of another." 30
The Alabama Supreme Court in Rosemont, Inc. v. Marshall, ${ }^{31}$ reversed a jury verdict in favor of the plaintiff who suffered a fatal injury after escaping a vest restraint and leaving the building, where she fell. The trial court had allowed the jury to render a verdict in the case even though the plaintiff had produced no expert testimony on the appropriate standard of care. The attending physician had indicated in his progress notes that the resident needed "total 24-hour nursing care." He testified that the resident was a "Houdini" and could "slip out of the vest restraints literally like a snake." $32 \mathrm{He}$ also testified that what he had meant by 24 -hour nursing care was "to have somebody eyeball [her] 24 hours a day." 33

The Supreme Court held that "the degree of care, skill and diligence" required of the facility in this case was not within the common knowledge of the lay jury. ${ }^{34}$ Instead, the court noted, "[i]ntermediate nursing facilities... are not prisons or asylums.... It is, therefore, incumbent upon such facilities not only to care for their patients in the medical sense, but to provide some atmosphere of homelife for them also." 35 The Court also found that the question whether the facility should have stationed guards or placed alarms on all doors would be influenced by "applicable state and federal regulations governing such facilities, physician-imposed restrictions, and policy determinations within the industry," 36 thus requiring expert testimony.

These cases indicate that courts and juries do not automatically assume that a facility is at fault whenever a resident is injured. Caregivers who fear liability for not assuring that patients are restrained to avoid falls and wandering can take heart from these cases. Ironically, Brown and Rosemont illustrate the limitations of restraints in protecting patients. Restrained patients do not always stay restrained. In Brown, in particular, the relationship between the use of the tray chair and the injury the resident suffered in attempting to get free should have been explored.

Some cases in which the facility has been held liable have been careful to distinguish the duty owed by the facility from any "duty to restrain." For example, in Golden Villa Nursing Home, Inc. v. Smith, ${ }^{37}$ the resident had a history of wandering and was the subject of an individualized "total care plan" which called for close supervision to prevent her from wandering onto the highway in front of the facility. The resident did wander onto the highway, and the facility was held liable for damages both to the resident and to the driver of the motorcycle that struck her. On appeal, the appellate court affirmed the judgment against the facility. The issue identified by the courr was not whether restraints should have been used, but 
whether the resident, who was known to be a wanderer, should have been left on the front porch of the facility unsupervised for nearly one hour while two of the three staff members on duty were on a break.

In Booty v. Kentwood Manor Nursing Home, Inc. ${ }^{38}$ and Fields v. Senior Citizens Center, Inc. ${ }^{39}$ the facilities were held liable for injuries a resident suffered in a fall after having left the facility unattended. In both of these cases, the staff had intentionally disabled the door alarm system. Even though it is not clear from these cases that the plaintiff established that the resident exited the facility through one of the alarmed doors, the staff's sabotage of a system designed to prevent the very incident that occurred offers an almost irresistible basis for liability.

Advocates of the view that potential civil liability requires the use of restraints for known wanderers will certainly look to these cases. But reliance on these cases for the proposition that restraints must be used is mistaken.

A close examination of another selection of cases, although few in number, reveals that fear of liability on the part of nursing homes for these injuries may not be entirely unreasonable. They also illustrate how private litigation can establish standards that encourage the routine use of restraints.

Courts holding a facility liable for failure to restrain have taken care to describe the reason for the initial placement in the facility as a concern for the safety of the resident. For example, one court noted that a nursing home resident who was successful in her claim against the facility for injuries she suffered in a fall "had been placed [in the facility] because she had fallen at home, had experienced periodic dizzy spells, and seemed confused or disoriented." 40 In another case in which the children successfully sued a facility for the death of their father who left the facility unattended, the court noted that the resident "was placed in the home specifically because his children desired that he receive more observation and occasional restraint than they were able to provide." 41 Other courts emphasize their view of a nursing home's primary role in the care of residents: "[ $t$ ] he very purpose of the duty is to protect patients who are physically able to move about, but mentally incapable of detecting danger, from situations that, while perhaps harmless to a healthy person, present a risk of harm to an elderly person in poor health." 42

If appropriately limited, these statements merely establish that a nursing home must take into account the particular needs of its patient population. But they include some troubling assumptions as well. The strong emphasis on protection from injury contrasts with the complete absence of a statement of compet- ing needs for mobility and comfort. The statements also identify, inappropriately, the expectations of the children who have placed the resident in the nursing home as the controlling interest.

A small number of restraint cases hold that the appropriate use of restraints is not a question of medical judgment, but rather is within the common knowledge of a jury. In each of these cases, the plaintiff's claim that the facility was negligent in not using restraints was allowed to reach the jury without providing any expert testimony on the use of restraints under the particular circumstances. A requirement of expert testimony may raise the cost of litigation beyond the point of likely return on cases generally viewed as low award producers. ${ }^{43}$ In some cases, however, the courts' reliance on "common knowledge" rather than expert testimony on the use of restraints legitimizes misplaced assumptions that encourage excessive restraint of nursing home residents.

The trial court dismissed plaintiff's claim against the facility for injuries suffered in a fall from her wheelchair in Kujawski $v$. Arbor View Health Care Center. ${ }^{44}$ Plaintiff had argued that the facility should have used a "safety belt" to secure the resident in her wheelchair, but produced no expert testimony to support their claim. The facility argued that a ventral hernia which "puffed out from her stomach like a balloon" 45 complicated the use of restraints for this patient. The Court of Appeals affirmed the trial court's dismissal, but the Supreme Court reversed.

In McGillivray $v$. Rapides Iberia Management Ent. ${ }^{46}$ the facility was held liable for the death of a resident who wandered from the facility in cold weather and died of a heart attack. The trial court issued judgment against the facility stating that "the fact that this patient, who was elderly and had serious heart problems and had the habit of wandering off and for whom his family had authorized the use of restraints, was able to simply walk out of the facility...constitutes negligence on the part of the [facility]."47 Apparently, the trial court concluded that the event itself proved negligence.

While the appellate court affirmed the trial court's conclusion of negligence, it limited its concurrence. The court stated, in italicized print, that " $[t]$ he findings ... refer not to the failure of the nurses to place Mr. Fox in the harness that night, but to their failure to guard against his leaving the premises." 48 The nurse had checked on Mr. Fox at 2:00 a.m., at 3:15 a.m. and again at 3:30 a.m. at which time he was sitting up in bed but said that he was about to go back to sleep. When she checked on him at 4:00 a.m. after her break, he was gone. ${ }^{49}$ He was found dead 15 to 30 minutes later in an adjoining parking lot. 50 
The courts are correct to conclude that safety is within the duty of nursing homes and that nursing homes retain some responsibility in decision-making on restraints. Nor are they incorrect in concluding that restraints may be appropriate under certain circumstances. But the evidence on the effects of restraints and current thought among the geriatric professions on the appropriate balance of the risks of non-restraint and the burdens suffered by restrained patients should inform this litigation as well.51 Relying on "common knowledge" as a source of the standard of care may in some cases hold facilities to standards that do not reflect current understanding of the use of restraints.

Intuitively, facilities believe that they face a substantial risk of liability for injuries related to falls and wandering. The low incidence of claims against nursing homes challenges the "fear of liability" as inflated. The fact that over 25 percent of the claims filed do involve injuries in falls or wandering, however, indicates that among the rather low liability risks facing nursing homes, these injuries are a substantial source of risk. An examination of reported cases indicates that the majority of the cases distinguish between the event, especially in the case of falls, and negligence on the part of the facility.

There are two strategic legal responses to situations in which fear of liability is claimed as a motive for engaging in undesirable behavior. The first is to encourage litigation against the undesirable behavior, in this case the excessive use of restraints, in order to neutralize the impact of potential liability in decisionmaking.

A few dramatic cases have been brought against nursing homes by residents claiming false imprisonment. In Big Town Nursing Home v. Newman, ${ }^{52}$ for example, the plaintiff claimed that the nursing home confined him against his will. Specifically, the facility prohibited him from using the telephone or receiving visitors, physically returned him to the facility when he escaped, and restrained him for hours at a time by taping him in a chair. Plaintiff also claimed that he had been confined with "senile patients, drug addicts, alcoholics, mentally disturbed [patients]" 53 and others. The jury rendered a verdict in favor of plaintiff on a claim of false imprisonment. The appellate court affirmed. But these cases are rare. ${ }^{54}$

More common are cases brought for serious physical injuries caused by the misapplication of restraints or failure to monitor restrained patients. For example, a jury in Houston recently returned a verdict for $\$ 39.4$ million in such a case against a nursing home. In this case, the 84 -year-old resident had been restrained in her bed with a vest-type restraint and was found hanging from the side of the bed strangled by the vest.55 One report of this case indicates that the resident had been restrained without the consent of her physician or her family for three nights. 56

Creating a "damned if you do, damned if you don't" situation is not an attractive strategy. Aside from the appearance of unfairness that it communicates to providers and the resultant lack of confidence in the legal system that it engenders, the strategy simply may not work. The database on cases filed against nursing homes reports only four cases alleging inappropriate physical and chemical restraints, compared to sixty claims for injuries due to falls. ${ }^{57}$ Cases involving fatal injuries do not address the more common situation of losses of mobility and general physical decline attributable to the inappropriate use of restraints.

The second strategy is to prohibit the undesirable behavior directly through regulation. In the context of examining the fear of liability relating to restraints, regulatory standards are of interest for the role they play in litigation.

\section{Public Regulation}

Many states include residents' rights provisions as part of the regulatory scheme applicable to nursing homes. ${ }^{58}$ The federal statute has included a residents' rights section since 1979.59 The current federal statute provides that residents have "the right to be free from...any physical or chemical restraints imposed for purposes of discipline or convenience and not required to treat the residents' medical symptoms." 60 The statute requires that restraints may be used only to ensure the physical safety of the resident or other residents and only when ordered by a physician in writing. ${ }^{61}$ These regulatory standards have begun to play a role in private litigation involving restraints.

Several states provide a statutory private right of action to nursing home residents or their representatives for violations of residents' rights provisions. ${ }^{62}$ Plaintiffs have been successful in a few reported cases in using these statutes. For example, in Stiffelman $v$. Abrams,${ }^{63}$ the plaintiff successfully claimed that physical abuse by a facility's employees was a violation of the residents' bill of rights and supported a claim under Missouri's private right of action. 64 These statutes are best read, not as creating a new cause of action or as relieving plaintiffs of the duty to prove breach of the statutory duties or causation, but rather as providing standing to residents to claim compensa- 
tion for breach of duties established in licensure; enhancing damages; and providing attorneys' fees. 65

A number of nursing home cases have rejected attempts to use regulatory standards as proof of the standard of care in clinical decision-making. For example, in Makas $\nu$. Hillhaven, ${ }^{66}$ the court rejected plaintiffs argument that breach of the statutory residents' bill of rights established negligence per se when the actions of the facility required some level of professional judgment. ${ }^{67}$ Courts have been equally resistant to attempts by defendant facilities to use their general compliance with licensure standards as proof of their satisfaction of the required standard of care. 68

Defendant facilities have offered public regulations on the use of restraints to support the claim that the plaintiff must produce expert testimony on the standard of care in order to reach the jury. Although this argument persuaded the trial court and the court of appeals in Kujawski v. Arbor View Health Care Center, ${ }^{69}$ the state supreme court rejected it. The state's nursing home statute defined physical restraints as items used "primarily to modify resident behavior" and "which the resident is unable to remove easily." The court distinguished the use of a safety belt in this case as "nonmedical, administrative, ministerial or routine care,"70 distinguishing it from the restraints governed by the statute and holding that the determination of whether to use a restraining belt involved "a matter of routine care within a jury's common knowledge." 71

This argument has met with some success, however. ${ }^{72}$ In Fine $\nu$. Woodside Manor Nursing and Convalescent Home, ${ }^{73}$ an unreported case, the Ohio Court of Appeals discussed the statutory restrictions on the use of restraints at some length. Plaintiff filed suit against the facility alleging that it was negligent in allowing the decedent resident to wander the halls unsupervised where he fell and suffered serious injuries. The nursing home filed a motion for summary judgment when the plaintiff indicated that she did not plan to use an expert witness to testify on the standard of care.

Defendant argued that Ohio's nursing home residents' rights statute required expert testimony on the use of restraints. This statute provided that residents had a right to be free from physical restraint except "to the minimum extent necessary and upon authorization in writing by a physician."

The court of appeals analyzed the statute differently. If the statute required a physician's written authorization for restraints, then expert testimony would be irrelevant. Without the authorization, the facility had no right, much less a duty, to use restraints. (The parties conceded that the case did not meet the statutory exception for the emergency use of restraints.)

The court shifted the focus away from the facility's alleged duty to restrain the patient to the facility's duty "to require a physician to examine the decedent in order that the decision to restrain might properly be made under the statute." The appellate court held that securing an examination of the resident was an administrative duty which would be within the common knowledge of the jury and would not require proof by expert testimony.

Finally, the defendant argued that expert testimony would still be required to prove that a physician under these circumstances would have ordered restraints, a question framed by the appellate court as one involving proximate cause. The appellate court returned the case to the trial court for a decision on the need for expert testimony as to this question. The remand to the trial court for resolution emerged from the courts' view that plaintiff had not had an opportunity to respond to that issue in planning her litigation strategy.

The analysis of the restraints statutes in Kujawski and in Fine offers a useful contrast. The analysis in Fine is superior to that in Kujawski as a general matter. It is sensitive to the role of medical judgment in regulation of the use of restraints. It recognizes that under current regulations the administrative authority to order restraints is very narrowly drawn and correlates liability with capacity. Yet it does not relieve the facility of all responsibility. ${ }^{74}$ In particular, the facility in Fine is held to its duty to communicate changes in the resident's condition to a physician. Applying this analysis to Kujawski, the facility would have a duty to notify the physician of the need for restraint and secure an examination of the patient. The judgment on the restraint would remain a medical judgment. The result in that case may well remain the same, but it would avoid encouraging a facility to itself decide under what circumstances to restrain and the type of restraint to use. If private litigation carries a regulatory message, that message should be clear and should be in line with regulatory goals established publicly.

It is likely that courts will be somewhat deferential to a physician's judgment in decision-making on restraints, at least insofar as it relates to the facility's liability. What may occur over time, of course, is a shift toward physician liability for malpractice in the use of restraints. One impact of such a shift could be a change in the assumptions on the use of restraints, including a clear identification of restraints as falling within professional judgment rather than administrative routine. Of course, legal standards do sometimes create perverse incentives. If physicians develop 
heightened fear of liability for failure to use restraints, a powerful alliance of administrative convenience and defensive medicine may occur. In addition, bureaucratic implications, such as a requirement that such claims be filed with a medical malpractice screening panel or tribunal must be separately considered and adjusted for their adverse impact on very elderly plaintiffs.

Physicians already play a pivotal role in regulatory restrictions on the use of restraints in nursing homes. The federal regulations and many state regulations governing nursing homes require a physician's written authorization for the use of restraints. The policy supporting these regulations is that requiring physician authorization for restraints should bring to bear the professional ethic and judgment of the physician. It is assumed that the physician will value the well-being of his or her patient more highly than the administrative routine of the institution. This should constrain the use of restraints, but only if physicians themselves do not share the expectations and customs that have supported the overuse of restraints. Moving the written authorization from a mere recordkeeping device toward an improvement in the quality of care depends in large part on physician attitudes and competency in geriatric care.

The quality of physician participation in the medical care of nursing home residents has been severely criticized. A recent article in the Journal of the American Medical Association charges that:

... very few [physicians] who do provide care for substantial numbers of nursing home residents have received formal training in geriatric medicine or long-term care. Physician visits are often brief and superficial, treatable conditions such as depression and incontinence are frequently underdiagnosed or misdiagnosed, many drugs are prescribed for unclear or inappropriate reasons, and psychotropic drugs are overused and misused in the absence of any input from mental health professionals. ${ }^{75}$

Physicians who do treat patients in nursing homes are hampered by some of the same constraints as nursing home administrators, including reimbursement systems that have not valued the labor intensive alternatives to restraints, such as periodic assessment of patients by qualified mental health specialists. Current medical practice in nursing homes is also limited by the knowledge-base for treatment of the very elderly. 76 Finally, physicians are subject to the same frustrations as other caregivers: " $[\mathrm{A}] \mathrm{n}$ ever-increasing number of patients . . . are agitated and noisy to the point of being antisocial and hard to live with. . . The problem is the patients." 77 The assumption that physicians will serve effectively as the protectors of nursing home patients should not be overdrawn.

Effective public regulation is necessary if the attitudes and supports favoring inappropriate restraints are to be changed and if the men and women currently living in nursing homes are to be free of excessive restraint. Relying solely on the family, the doctors and other caregivers to reject restraints is premature because the supports for the use of restraints are planted quite deep.

The development of reliable indicators to distinguish appropriate and inappropriate uses of restraints is challenging. This task presents ethical, as well as medical and legal, issues. It requires a choice among competing goals of "how best to balance individual residents' rights, to guard their dignity, to prevent unnecessary medical problems, and at the same time to protect the broader needs of the other residents and the nursing home community at large."78 Institutional ethics committees in nursing homes can contribute significantly to the development of policies on the use of restraints. ${ }^{79}$ A structured role for an analysis of the ethical issues involved in the use of restraints can help to balance and clarify the now-dominant legal and regulatory concerns. 80

\section{Responses to the Risk of Liability}

Although "fear of liability" is a frequent defense for routine use of restraints, it should not be accepted as an excuse. The risk of liability should never become the determining factor in health care decision-making. The ethical duties of health caregivers to their patients are superior to a concern for avoiding liability. Health care is a risky business; risk goes with the territory.

But it is too cavalier to say simply that the risk of liability has to be tolerated as health care providers respond to a higher calling. When fear of liability contributes to undesirable behavior, it must be addressed analytically.

Nursing home administrators should first understand the nature of the risk. The low incidence of claims filed against nursing homes and the deference that a number of the reported cases show to the professional judgment involved in decisions not to use restraints should afford providers some measure of confidence in developing policies that reject the routine use of restraints. In addition, the sources of the risk of liability must be examined. The risk of injuries due to falls, for example, is not eliminated through 
the use of restraints. Restraints may contribute to the fall or to the severity of the injury suffered. The fact that a facility had restrained a patient who fell does not relieve it of liability. ${ }^{81}$ Finally, the risk of liability can be better managed. Nursing homes can work with the families of residents and residents themselves to assure that these "potential plaintiffs" understand the limitations and risks of restraints and the benefits and risks of continued mobility. Nursing homes must understand their duties in relation to restraints more precisely. These duties include securing medical authorization for restraints and providing alternative means of protecting high-risk residents.

If case law relating to the perceived risk in fact conflicts with the goal of reducing the inappropriate use of restraints, change in the way this issue is handled by the courts is required. The context of litigation over injuries to nursing home residents may be overly risk-averse in its reflection of assumptions concerning the primary goal of long-term care. Reliance on common knowledge may elevate risk-aversion over other goals. Common knowledge on the use of restraints is suspect for other reasons as well. Empirical evidence on the use of restraints is counterintuitive: they can cause physical injuries and they may increase agitation.

Public regulation of the use of restraints offers a new model that views restraints as medical treatment requiring medical judgment. Enforcement of these regulations has not been a priority, and the effectiveness of regulatory restrictions on the use of restraints must be further evaluated. But even this model appears to be incomplete: it relies too heavily on physicians to defy the structural biases supporting restraints and minimizes the remaining duty of administrators and nurses to monitor physician behavior regarding restraints.

The overuse of restraints reflects conflict over the most fundamental issues in long-term care. It reveals ambivalence over public expectations for nursing home care for the elderly. Ambivalence over goals influences the allocation of resources to achieve those goals. The hospital model of nursing home care, for example, assumes staffing patterns that focus on efficient delivery of care in an acute-care setting and that may not be effective in meeting the multiple needs of long-term residents of nursing homes, including needs compromised by the inappropriate use of restraints. The medical profession does not know enough about the medical and other needs of elderly people, particularly in long-term care, both as a matter of education for physicians and as a matter of medical research.

The overuse of restraints is a symptom of inadequate models for long-term care, not simply a naive reaction to a fear of liability. The fear of liability should not be used as a scapegoat. The true causes of excessive use of restraints in nursing homes lie elsewhere.

\section{References}

The author gratefully acknowledges the contribution of Debra Schuster, a student in the 1989 Law and Aging Seminar at the School of Law, for her work on the social and medical issues in the use of restraints.

1. Routine use of restraints is that which is not supported by a diagnosis of the cause of the behavior to be restrained, by an assessment of the effectiveness of the restraint in modifying that behavior, the risks posed by the restraint and a consideration of alternatives that pose less risk to the patient. The Institute of Medicine study of nursing home care identified excessive use of restraints (judged by the number of residents restrained in a facility in light of the number of the facility's residents "at risk" for restraints) as a measurement of poor care. Institute of Medicine, Improving the Quality of Care in Nursing Homes 84, 116, 118,121 (1986).

2. See discussion at notes $5-12$, infra.

3. See discussion at notes 58-61, infra.

4. J. Ouslander, "Medical Care in the Nursing Home," 262 JAMA 2582, 2587 (November 10, 1989)[hereinafter Medical Care]; M. Beers, J. Avorn, S. Soumeral, D. Everitt, et al., "Psychoactive Medication Use in Intermediate Care Facility Residents", 260 JAMA 3016 (November 25, 1988).

5. L. Snyder, P. Ruprecht, J. Pyrek, et al., 18 The Gerontologist 272 (May/June 1978); N. Strumpf, and L. Evans, "Physical Restraints of the Hospitalized Elderly: Perceptions of Patients and Nurses," 37 Nursing Research 132 (May/June 1988)

6. L. Evans, N. Strumpf, "Tying Down the Elderly: A Review of the Literature on Physical Restraint," $37 \mathrm{~J}$. Am. Geriatric Society 65 (1989) [hereinafter, Tying Down]; H. Rubenstein, F. Miller, S. Postel, H. Evans, "Standards of Medical Care Based on Consensus Rather Than Evidence: The Case of Routine Use of Bedrails for the Elderly," 11 Law, Medicine of Health Care 271 (1983).

7. A. Dube, and E. Mitchell, "Accidental Strangulation from Vest Restraints," 256 JAMA 2725 (November 21, 1986).

8 Harper and Lyles, "Physiology and Complications of Bed Rest," 36 J. Am. Geriatric Society 1047 (1986).

9. J. Cohen-Mansfield, "Agitated behaviors in the Elderly: Preliminary Results in the Cognitively Deteriorated," 34 J. Am. Geriatric Society 722 (1986).

10. Examples of misdiagnoses attributable to the use of restraints include two described during hearings on the use of restraints in nursing homes. An 85-year-old woman who had fallen out of bed was returned to bed and restrained to prevent another fall. Her agitation and screaming over several weeks were "treated" with further restraints. Finally, it was discovered that the woman had suffered a neck fracture in the earlier fall. In another incident, a patient receiving multiple medications was diagnosed as psychotic and medicated with an additional drug, this time an anti-psychotic medication. After some time, it was discovered that she suffered from a drug-induced psychosis which would be treat- 
able by altering her earlier medications. Drug Abuse in Nursing Homes, Hearings Before the Congressional Commirtee on Aging, 100th Congress, 1st Session (1980) at 86 and at 59 .

11. Strumpf and Evans, "Physical Restraints of the Hospitalized Elderly: Perceptions of Patients and Nurses," 37 Nursing Research 132 (May/June 1988).

12. Tying Down, supra note 6; R. Tiderksaar, "Geriatric Falls: Assessing the Cause, Preventing Recurrence," 44 Geriatrics 57 (1989).

13. " $[\mathrm{C}]$ ontinued poor reimbursement to nursing homes and other long term care facilities - by the federal government in particular - very well may stop the move to a restraint-free environment in its tracks." Brodeur, "LongTerm Care: How Necessary Are Physical and Chemical Restraints?" 5 Issues 1 (Jan. - Feb. 1990).

14. Regulations relating to minimum space and design requirements may impede changes in environmental designs that will minimize dangers to ambulatory patients. See generally, Environmental Design, Supp. to AAHA Provider News (July 31, 1987).

15. Several researchers have suggested that a reorganization of staffing from shifts of workers with specialized job assignments to teams who work with particular residents on a continuous basis would foster higher job satisfaction and more responsiveness to the individual needs of residents. See e.g., Ramian, "The Resident Oriented Nursing Home: A New Dimension in the Nursing Home Debate Emphasis on Living Rather Than Nursing," 5 Danish Medical Bulletin 89, 91 (1987); Cherau, "Permanent Team Assignments: Quality Care That Makes Good Sense," Nursing Homes 22 (July/August 1983). An administrator of a multi-facility nursing home organization reports that nine of their facilities have reduced their use of restraints "without increasing falls, staff or costs." Benac, "Nursing Homes Turn Away from Tethering the Elderly," Los Angeles Times, January 7, 1990; Part A; page 2; column 1 (from NEXIS).

16. "[Long-term care] is plagued by an overriding sense that the clientele are in inevitable decline ..." Kane and Kane, "Long-Term Care: Variations on a Quality Assurance Theme," 25 Inquiry 132, 132 (Spring 1988).

17. Holder, "A Consumer Perspective on Quality Care: The Resident's Point of View," 5 Danish Medical Bulletin 84,87 (1987). The residents surveyed had lived in the nursing home an average of four years. One-third were over 80 ; and one-third were in their 70 s. $41 \%$ used wheelchairs and $50 \%$ needed assistance in getting around. At 86 .

18. Callopy, "Autonomy in Long Term Care: Some Crucial Distinctions," 28 The Gerontologist 10, 10 (Supp. 1988).

19. Benac, "Nursing Homes Turn Away from Tethering the Elderly," Los Angeles Times, January 7, 1990, Part A; page 2; column 1 (from NEXIS).

20. Francis, [Letter] "Using Restraints in the Elderly Because of Fear of Litigation," 120 New Eng. J. Med. 87 (Mar. 30, 1989).

21. Several of the reported cases involve injuries that were ultimately fatal to the nursing home resident. For example, a patient who fell outside the facility suffered a broken shoulder and died the next morning of blod clots in her lungs that were caused by the shoulder fracture (Rosemont, Inc. v. Marshall, 481 So.2d 1126, 1129 (Ala. 1985)). Another patient, who fell out of her wheelchair, suffered a broken leg which later was amputated when it failed to heal properly (Kujawski v. Arbor View Health Care Ctr., 407
N.W.2d 249 (Wis. 1987)).

22. Kane and Kane, supra note 16 at 132.

23. P. Danzon, Medical Malpractice: Theory, Evidence, and Public Policy 74 (1985).

24. See generally, Butler, "Nursing Home Quality of Care Enforcement: Part I-Litigation by Private Parties," 14 Clearinghouse Review 622 (1980); McNath, "The Nursing-Home Maltreatment Case," 21 Trial 52 (Sept. 1985); Nemore, "Protecting Nursing-Home Residents," 21 Trial 54 (Dec. 1985); S. Johnson, N. Terry \& M. Wolff, Nursing Homes and the Law: State Regulation and Private Litigation (1985).

25. The MEDMAL database, available through Westlaw, covers cases filed from January 1986. A search in January 1990, on which these statistics are based, covered four years. The database lists filings in all U.S. District Courts and in trial courts of general jurisdiction in 52 cities (including Los Angeles, Washington, D.C., Boston, Atlanta, San Francisco, Philadelphia and Miami). It also includes cases filed with the medical practice review panels in Indiana, Louisiana, Maryland and Wisconsin. Although the database titles itself MEDMAL, cases filed against nursing homes included premises liability cases and cases filed by employees for workplace injuries. The database is not necessarily comprehensive for each of the courts included.

26. 245 So.2d 544 (La. App. 1971).

27. 549 So.2d 395 (La.App. 1989).

28. 496 S.W.2d 503 (Tenn.App. 1972).

29. Plaintiff argued on appeal that the trial court should have instructed the jury on res ipsa loquitur rather than on negligence. The Court of Appeals affirmed the trial court's instructions. At 509.

30. Id.

31. 481 So.2d 1126 (Ala 1985).

32. ld. at 1129 .

33. Id. at 1129 .

34. Id. at 1130 .

35. Id.

36. Id.

37. 674 S.W.2d 343 (Tex. App. 1984). See also, Associated Health Systems $v$. Jones, 366 S.E.2d 147 (Ga. App. 1988), in which the court held that statutory restrictions on the use of restraints did not prohibit the nursing home from restricting a violent resident to certain areas of the facility.

38. 483 So.2d 634 (La.App. 1985).

39. 528 So.2d 573 (La.App. 1988).

40. Smith v. Gravois Rest Haven, Inc., 662 S.W.2d 880, 882 (Mo. App. 1983).

41. McGillivray v. Rapides Iberia Management Ent., 493 So.2d 819, 823 (La. App. 1986).

42. Id. at $824-825$.

43. See generally, Johnson and Dodson, "Decreasing Exposure to Liability in Long-Term Care," 67 Healt $b$ Progress 18 (Oct. 1986). Recoveries in the cases discussed in this article include awards of $\$ 100,000$ in the case of a resident who left the facility unnoticed in 42 degree weather and suffered a fatal heart attack (McGillivray $\nu$. Rapides Management Ent., 493 So.2d 819 (La. App. 1986)); over $\$ 300,000$ to the surviving spouse and children of a resident who left the facility unobserved and was run over by his own daughter (Fields v. Senior Citizen Center, Inc., 528 So.2d 573 (La. App. 1988)); and $\$ 20,000$ for injuries suffered in falling from bed (Smith v. Gravois Rest Haven, Inc., 662 S.W.2d 880 (Mo. App. 1983)).

44. 407 N.W.2d 249 (Wis. 1987). 
45. Id. at 251

46. 493 So.2d 819 (La.App. 1986).

47. Id. at 823

48. Id. at 823

49. Id.

50. Id.

51. The author of the letter to the New England Journal of Medicine quoted earlier argues that "I believe it is time to put the responsibility for setting the standard of care back in the hands of the medical and nursing professions, with the interests of patients in mind, instead of allowing the agenda to be set by concern for liability." Francis, supra note 20 .

52. 461 S.W.2d 195 (Tex. Civ. App. 1970).

53. Id. at 197.

54. See, Kazin, "Nowhere to Go and Chose to Stay: Using the Tort of False Imprisonment to Redress Involuntary Confinement of the Elderly in Nursing Hornes and Hospitals," 137 U. Penn. L. Rev. 903 (1989) for a detailed analysis of the legal, social and political issues that limit this type of litigation.

55. Green and Pollock, "Nursing Home is Liable in Restraint Case," Wall Street Journal, Section B, Page 5, Column 1 (March 26, 1990).

56. Woolsey and Bradford, "Two Separate Texas Juries Award $\$ 40$ Million for Wrongful Deaths,"Business Insurance, Section ECFC; Page 3 (April 9, 1990) (from NEXIS). This article reports that the amount awarded was $\$ 40.6$ million.

57. See note 25 supra.

58. More than half the states and the District of Columbia have residents' rights statutes. (As listed in Note, Don't Make Them Leave Their Rights at the Door: A Recommended Model State Statute to Protect the Rights of the Elderly in Nursing Homes, $4 \mathrm{~J}$. of Contemp. Health Law and Policy 321, 326 (1988)).

59. Kapp, Preventing Malpractice in Long-Term Care 98 (1987).

60. 42 U.S.C. $1395 i-3(\mathrm{c})(1)(\mathrm{A})(\mathrm{ii}) ; 42$ L.S.C. $1396 \mathrm{r}(\mathrm{c})(1)(\mathrm{A})(\mathrm{ii})$. The final regulation on the restraints provision removes the issue of the use of restraints from the residents' rights section and places it in a section on -Resident behavior and facility practices." The Secretary explains the move: "Because the area of behavioral management of nursing facility residents has both residents' rights and quality of care dimensions, we are placing proposed 483.10 (d), Restraints, and $483.10(\mathrm{e})$, Abuse, in a new requirement. ..." 54 Fed. Reg. 5316, 5322 (Feb. 2, 1989). The effective date of these regulations, which has been delayed several times, is October 1, 1990. 54 Fed. Reg. 53611-01 (Dec. 29, 1989).

61. Id.

62. See generally, S. Johnson, N. Terry and M. Wolff, Nursing Homes and the Law: Public Regulation and Private Litigation 1-22 (1985); Hoffman and Schreier, "A Private Right of Action Under Missouri's Omnibus Nursing Home Act," 24 St. Louis L. J. 661 (1981).

63. 655 S.W.2d 622 (Mo. 1983).

64. See also, Harris $\nu$. Manor Healthcare Corp.. 489 N.E.2d 1374 (Ill, 1986), in which the Illinois Supreme Court upheld the punitive damages provision of the statute against constitutional challenge.

65. See e.g., Begandy v. Richardson, 510 N.Y.S. 2d 984 (N.Y. Sup. Ct. 1987). For further discussion of the private right of action and enforcement of residents' rights, see
Johnson, "State Regulation of Long-Term Care: A Decade of Experience with Intermediate Sanctions," Law, Medicine of Health Care 13, 179-180 (Sept. 1985).

66. 589 F.Supp. 736 (D.N.C. 1984).

67. See also, Stogsdill v. Manor Convalescent Home; Inc., 343 N.E.2d 589 (Ill. App. 1976). See discussion of the use of regulation as proof of standard of care in S. Johnson, N. Terry, \& M. Wolff, Nursing Homes and the Law: Public Regulation and Private Litigation 3.21 (1985).

68. See e.g., Golden Villa Nursing Home, Inc. v. Smith, 674 S.W.2d 343 (Tex. App. 1984). See also, Associated Health Systems v. Jones, supra note 37.

69. 407 N.W.2d 249 (Wis. 1987).

70. Id. at 252 .

71. Id. at 251 .

72. In Rosemont $v$ Marshall, as discussed previously, the court briefly. referred to regulatory standards in holding that plaintiff was required to present expert testimony on the standard ot care. At 1130. In Nichols $v$. Green Acres Rest Home, Inc., 245 So.2d 544 (La. App. 1971), the court referred to regulatory requirements concerning staffing and prohibiting locked doors and institutional policies requiring that restraints be used only under a physician's order in upholding a jury verdict in favor of the defendant facility.

73. 1984 WL 6860 (Ohio App.).

74. Nursing home administrators and nurses also exercise some professional judgment relative to restraints. In a license revocation proceeding, an administrator argued that deficiencies in the facility concerning the performance of the medical director's supervision of medical treatment and the excessive use of restraints were not his responsibility and should not support revocation of his license. The Board of Examiners of Nursing Home Administrators and the reviewing appellate court held that the administrator had sufficient notice of the incompetence of the medical director and that it was the administrator's duty to monitor the performance of department heads. The court held that the administrator's failure to secure a professional consultant to evaluate the medical director constituted unethical conduct and supported license revocation. Harrow $\nu$. Axelrod, 538 N.Y.S. 2d 103 (N.Y. App. Div. 1989).

75. Ouslander, Medical Care in the Nursing Home, 262 JAMA 2582, 2582 (Nov. 10, 1989). Citations omitted.

76. Id.

77. Letter to the Editor by Nicholas L. Owen, M.D., American Medical Directors Association, JAMA 261:2068 (4/14/89).

78. Brodeur, supra note 13.

79. A national survey of ethics committees in nursing homes indicated that such committees were relatively new and existed in only 2 to 8 percent of all nursing homes. Glasser, Zweibel, and Cassel, "The Ethics Committee in the Nursing Home: The Results of a National Survey," $36 \mathrm{~J}$. Am. Geriatrics Soc. 150,151 (Feb. 1988). Of the nursing home ethics committees responding to the survey, $54 \%$ reported having considered the use of restraints in the context of a case review and $42 \%$, in the context of policy discussions. Id. at 153 .

80 . In the national survey of nursing home ethics committees, nursing homes reported that they relied on regulatory requirements and legal advice to guide decision-making in cases raising ethical conflicts. Of the facilities responding, $61 \%$ relied on institutional policies for decision-making. The factors motivating the development of these policies were regulatory requirements (reported by $84 \%$ of the 
respondents) and a desire to reduce legal liability (reported by $75 \%$ ). Thirty percent of the responding facilities reported seeking legal advice for ethical dilemmas in patient care while $9 \%$ sought guidance from ethicists. Id. at 153 .

81. See, e.g., Dusine $v$. Golden Shores Convalescent Center, Inc., 249 So.2d 40 (Fla. App. 1971), in which the appellate court overturned the trial court's directed verdict for the defendant facility in a case in which a resident was injured when she fell from her wheelchair. Although the resident had been restrained with a Posey vest, the court held that a jury could find the facility negligent for failing to monitor the resident over a twenty-minute period. 